\title{
ENHANCING EGGPLANT PRODUCTIVITY THROUGH IRRIGATION SCHEDULING REGIME AND FOLIAR SPRAY WITH CHITOSAN CONCENTRATES
}

\author{
Ahmed I. Aly ${ }^{1 *}$, F.R.M. Farrag ${ }^{2}$ and Nesrin F. Mohammed ${ }^{2}$ \\ 1. Hort. Res. Inst., ARC, Giza, Egypt \\ 2. Soils, Water and Environ. Res. Inst., ARC, Giza, Egypt
}

Received: 09/05/2019 ; Accepted: 15/10/2019

\begin{abstract}
Two Field trials were carried out at Abo-Gensho village, Abshway District, Fayoum Governorate, Egypt, during two successive summer seasons of the 2017 and 2018 to study the effect of irrigation scheduling treatments and foliar spray with chitosan concentrates on growth parameters, yield and its components and some water relations of eggplants cv. black beauty. Three irrigation scheduling treatments based on coefficients of cumulative pan evaporation (CPE), i.e. $\mathrm{I}_{1}: 1.1, \mathrm{I}_{2}: 0.9$ and $\mathrm{I}_{3}: 0.7 \mathrm{CPE}$ with three chitosan concentrates, i.e. $\mathrm{C}_{1}: 0$ (without addition, control), $\mathrm{C}_{2}: 40$ and $\mathrm{C}_{3}: 80$ $\mathrm{mg}^{-1}$ with three replications in a strip plot design. Results indicated that the highest plant growth and eggplant fruits yield in both seasons were detected from a combination of irrigation at 1.1 CPE and spraying by $80 \mathrm{mg} \mathrm{l}^{-1}$ as chitosan concentrate. Further, it resulted in highest values for seasonal consumptive use $\left(\mathrm{ET}_{\mathrm{C}}\right)$ as well as water use efficiency (WUE). On other hand, it could be recommended the combination of irrigation at $0.9 \mathrm{CPE}$ and applying $80 \mathrm{mg} \mathrm{l}^{-1}$ as chitosan concentrate in Egypt for enhanced eggplant fruits yield especially under deficit irrigation water conditions.
\end{abstract}

Key words: Eggplant, irrigation scheduling, chitosan concentrate, water consumptive use, water use efficiency.

\section{INTRODUCTION}

Eggplant (Solanum melongena L.) is a member of the Solanaceae family, which includes other main vegetable crops such as tomatoes, potatoes and capsicums. Eggplant is considered from the healthiest vegetables for its high content of bioactive compounds, minerals and vitamins in addition, a very low caloric value (Plazas et al., 2013; Docimo et al., 2016).

Water deficit is one of the most limiting factors in agricultural sector in arid and semiarid regions. Water management strategies including rationalizing and saving irrigation water plays an important role to face the challenges of climate changes which make water resources became more restricted. Regarding the effect of irrigation, water stress led to reduction in the fruit characteristics like; height, diameter

\footnotetext{
*Corresponding author: Tel. : +201028587700

E-mail address: Ahmedelbawa250@yahoo.com
}

and weight which significantly reduce fresh yield (Kirnak et al., 2002; Chaves et al., 2003). Eggplant is considered a moderate tolerant to water stress at $67 \%$ crop evapotranspiration (D'iaz- Perez et al., 2015; Abdalla et al., 2018). Irrigation every short interval gave the highest averages of fresh yield and water use efficiency compared with irrigation at medium and long intervals (Amiri et al., 2012; Inalpulat et al., 2014; Abdalla et al., 2018).

Chitosan is a natural polysaccharide, low toxic and inexpensive compound that is biodegradable and environmentally friendly with various applications in agriculture when the nitrogen contained in the Chitosan is dissolved, it penetrates gradually and remains in the soil for a long period of time and so does its effect, (Becker et al., 2000). Chitosan also improves the plants growth and considered as a powerful 
pesticide substance when added to the carboxyl methyl cellulose or methyl cellulose, as its effectiveness can be far better than any other pesticide used for plant's disease resistance (Fig. 1).

Chitosan is belongs to carbohydrate family which can be extracted from the marine crustacean lie; cramp, pinfish and shrimps or most insects from their exoskeletons (Sugiyama et al., 2001). Chitosan contains two nitrogen atoms in its chemical formula $\left(\mathrm{C}_{11} \mathrm{H}_{17} \mathrm{O}_{7} \mathrm{~N}_{2}\right)$, which considered one of the major elements of plant nutrition that dissolves and remains in the soil for a long time (Becker et al., 2000).

In agricultural sector, chitosan uses as a fertilizer to development seeds, roots, shoots, leaves and fruits to increase plant production and protection from diseases (Gornik et al., 2008; Sheikha and Al-Malki, 2011; Mondal $e$ t al., 2012; Ibraheim and Mohsen, 2015). Moreover, chitosan has been shown to stimulate plant growth (Mondal et al., 2012), to possess antioxidant activity (Chen et $\boldsymbol{a l}$., 2009), act as antitranspirant compound that has proved to be effective in many crops (Karimi et al., 2012) as a plant growth regulator and considered to elicit the induction of plant defense mechanisms in many plants (Ben-Shalom et al., 2003; Photchanachai et al., 2006).

The objective of this study was to investigate the effect of irrigation cheduling treatments, rates of chitosan concentration and their interaction on plant growth, yield and its components as well as both water use efficiency (WUE) and seasonal consumptive use $\left(\mathrm{ET}_{\mathrm{C}}\right)$ of eggplant plant.

\section{MATERIALS AND METHODS}

\section{Site and Soil Description}

The current investigation was carried out during two successive summer seasons of 2017 and 2018 at Abo-Gensho Vellage, Ibshway District, Fayoum Governorate, Egypt (lat. $30 \mathrm{~m}^{+}$ mean sea level, lat. $29.18^{\circ} \mathrm{N}$; long. $30.51^{\circ} \mathrm{E}$.). Some soil physical and chemical properties for the trial site determined according to Klute (1986) and Page et al. (1982) and presented in Table 1. The soil moisture constants were gravimetrically determined on oven dry basis, as the technique of Water Requirements and Field Irrigation Dept., SWERI, Egypt for soil layers, down to $60.0 \mathrm{~cm}$ depth and recorded in Table, 2. The weather data were collected at the Etsa Agro Meteorological Station, Fayoum Governorate, and showed in Fig. 2.

\section{Experimental Details}

Eggplant seedling cv. black beauty, were transplanted on $1^{\text {st }}$ and $3^{\text {rd }}$ of May in the first and second seasons, respectively, on both sides of each ridge ( $1.5 \mathrm{~m}$ width and $7 \mathrm{~m}$ long) at a space of $0.5 \mathrm{~m}$ between plants. Each plot consisted of two ridges having an area of $21.0 \mathrm{~m}^{2}$, a guard row was left between each two adjacent plots. Fertilization as recommended doses were done and control of weeds, insects and diseases was carried out when it was necessary.

Three irrigation scheduling treatments, i.e. irrigation at 1.1, 0.9 and $0.7 \mathrm{CPE}$ (based on coefficient of cumulative pan evaporation, CPE) were integrated with three rates of chitosan concentrations, i.e. $\mathrm{C}_{1}: 0$ (without any addition control), $\mathrm{C}_{2}: 40$ and $\mathrm{C}_{3}: 80\left(\mathrm{mg} \mathrm{l}^{-1}\right)$ where applied twice as foliar spray) at vegetative growth (25 days after transplanting) and at flowering stage. The experiment included 9 treatmenrs which were the combinations between 3 irrigation treatments and 3 concentrations of chitosan. These treatments arranged in a strip plot design with three replications. To avoid the water lateral movement, allays $2 \mathrm{~m}$ were used to isolated between each two plots.

On determining the irrigation time, pan evaporation records was multiplied by the different adopted coefficient, and irrigation was practiced as the two sides of the following formula were the same.

Available soil moisture $(\mathrm{mm})$ in the root zone $=$ Pan evaporation record $(\mathrm{mm}) \mathrm{x}$ assessed coefficient (Abdou et al., 2018).

It is worthy to mention that irrigation scheduling treatments started from the $2^{\text {nd }}$ irrigation. Data of plant height $(\mathrm{cm})$, stem diameter (cm), leaves No., fruit No, fruit length $(\mathrm{cm})$, fruit diameter $(\mathrm{cm})$, fruit weight $(\mathrm{g})$ and fruit yield/fad., were recorded in 2017 and 2018 seasons. 


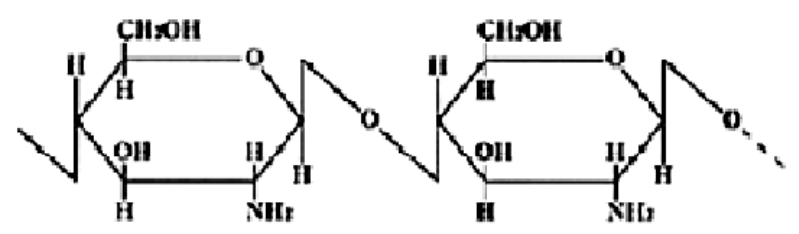

Fig. 1. The chemical structure of chitosan (George and Abraham, 2006)

Table 1. Some soil physical and chemical analyses of experimental site in 2017 and 2018 seasons (two seasons average)

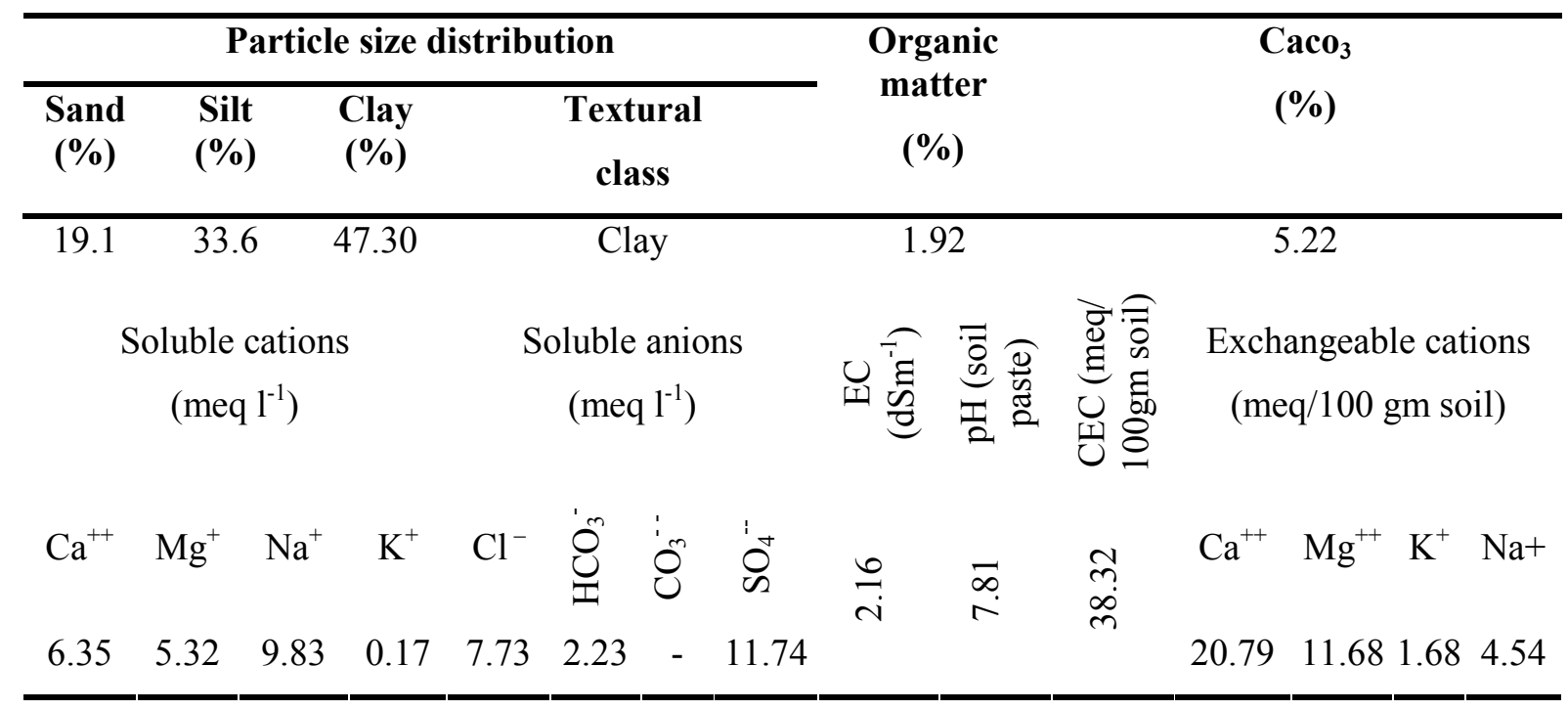

Table 2. Average values of some soil moisture constants and bulk density for the experimental field in 2017and 2018 seasons (two seasons average)

\begin{tabular}{cccccc}
\hline $\begin{array}{c}\text { Soil depth } \\
(\mathbf{c m})\end{array}$ & $\begin{array}{c}\text { Field capacity } \\
(\mathbf{\%}, \boldsymbol{W} / \boldsymbol{W})\end{array}$ & $\begin{array}{c}\text { Wilting point } \\
\mathbf{( \% ,} \boldsymbol{W} / \boldsymbol{W})\end{array}$ & $\begin{array}{c}\text { Bulk dnsity } \\
\left(\mathbf{g c m}^{-3}\right)\end{array}$ & $\begin{array}{c}\text { Available soil } \\
\text { moisture } \\
\mathbf{( \% ,} \boldsymbol{W} / \boldsymbol{W})\end{array}$ & $\begin{array}{c}\text { Available soil } \\
\text { moisture } \\
(\mathbf{m m})\end{array}$ \\
\hline $00-15$ & 45.81 & 24.36 & 1.28 & 21.45 & 41.18 \\
$15-30$ & 43.62 & 23.75 & 1.31 & 19.87 & 39.04 \\
$30-45$ & 41.01 & 23.42 & 1.37 & 17.59 & 36.15 \\
$45-60$ & 40.31 & 23.37 & 1.43 & 16.94 & 36.34 \\
\hline
\end{tabular}




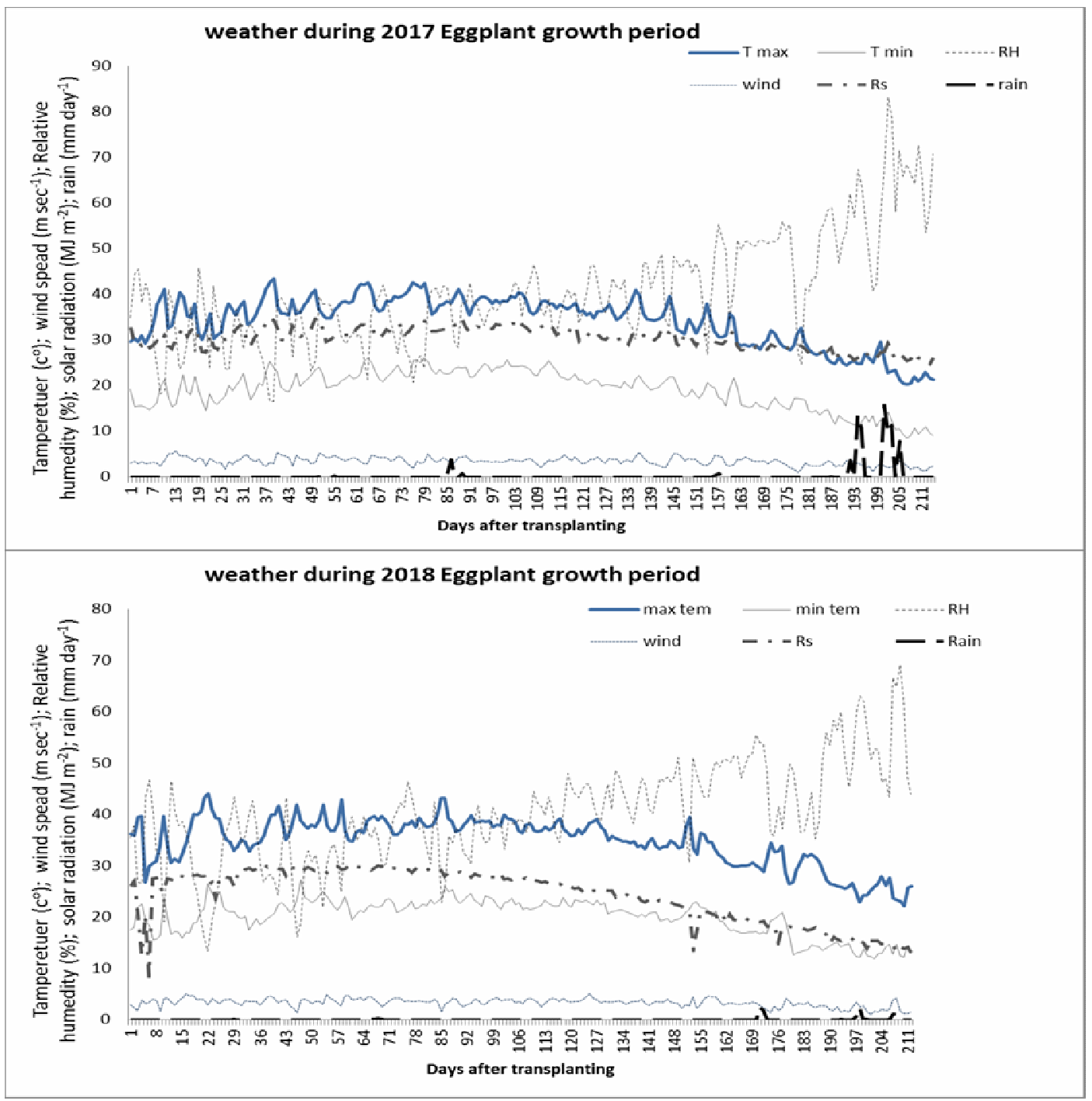

Fig. 2. Weather data for eggplant growing period during 2017 and 2018 seasons

The means of collected data were analyzed statistically using (MSTAT-C) and compared by LSD test at 5\% level (Gomez and Gomez, 1984).

\section{Crop-Water Relations}

\section{Seasonal consumptive use $\left(\mathbf{E T}_{\mathrm{C}}\right)$}

For determining the crop water consumptive use $\left(\mathrm{ET}_{\mathrm{C}}\right)$, soil samples were taken from each sub-plot, just before and after 48 hours from each irrigation, as well as at harvesting time and the $\mathrm{ET}_{\mathrm{C}}$ between each two successive irrigations was calculated according to the following equation (Israelsen and Hansen, 1962).
$\mathrm{Cu}\left(\mathrm{ET}_{\mathrm{C}}\right)=\left\{\left(\mathrm{Q}_{2}-\mathrm{Q}_{1}\right) / 100\right\} \times \mathrm{Bd} \times \mathrm{D}$

Where:

$\mathrm{Cu}=$ crop water consumptive use $(\mathrm{cm})$.

$\mathrm{Q}_{2}=$ soil moisture percentage 48 hours after irrigation.

$\mathrm{Q}_{1}=$ soil moisture just before irrigation.

$\mathrm{Bd}=$ soil bulk density $\left(\mathrm{gm} \mathrm{cm}^{-3}\right)$.

$\mathrm{D}=$ soil layer depth $(60 \mathrm{~cm})$.

\section{Water use efficiency (WUE)}

The water use efficiency as $\mathrm{kg}$ fresh yield $\mathrm{m}^{-3}$ water consumed was calculated for different treatments (Vites, 1965):

WUE $=$ fruit yield $\left(\mathrm{kg}^{-1}\right) /$ seasonal $\mathrm{ET}_{\mathrm{C}}\left(\mathrm{m}^{3} / \mathrm{fad}^{-1}\right)$. 


\section{RESULTS AND DISCUTION}

\section{Growth Parameters}

Results in Table 3 reveal that, the growth parameters were affected significantly by irrigation scheduling treatments. The highest averages of plant height, stem diameter and leaf No. were detected from irrigation eggplant at 1.1 (CPE). Whereas, the lowest ones were resulted from irrigation at 0.7 (CPE). Increasing irrigation scheduling coefficient from 0.7 to 1.1 (CPE) significantly increased the plant height, stem diameter and leaf No./plant by 8.6, 19 and $20.8 \%$, in 2017 and in 2018 seasons, respectively by $6.8,20$ and $20.5 \%$, respectively. The present results may be referred to the effect of soil moisture stress (under 0.7 CPE treatment) which may be responsible for reducing photosynthesis, cell division, stem elongation, leaf area, leaf duration and dry matter accumulation in plant organs (Amiri et al., 2012; Abdalla et al., 2018).

Regarding the foliar sprey of chitosan concentrates, results in the same Table 3 indicate that, applying chitosan concentrate of $80 \mathrm{mg} \mathrm{l}^{-1}$ gave the highest averages of the above mentioned growth parameters. Reducing the chitosan concentrate from $80 \mathrm{mg} \mathrm{l}^{-1}$ to $0.0 \mathrm{mg} \mathrm{l}^{-1}$ (without addition of the control treatment, significantly reduced plant height, stem diameter and leaf No in 2017 season by 3.2, 19.2 and $15.4 \%$, respectively and by 3, 20 and $14.9 \%$, respectively, in 2018 season. The positive effect of chitosan on plant growth may be attributed to an increment of the enzyme activities of nitrogen metabolism (glutamine created and protease as well as nitrate reduction), furthermore, increasing in photosynthesis process which encourage plant growth (Gornik et al., 2008; Mondal et al., 2012; Ibrahiem and Mohsen, 2015)

Results in Table, 3 indicate that the mentioned growth parameters were significantly affected by interaction between irrigation scheduling regimes and applying chitosan concentrates. The highest averages of plant height, stem diameter and number of leaves/plant resulted from irrigation eggplants at 1.1 CPE with applying chitosan at the rate of $80 \mathrm{mg} \mathrm{L}^{-1}$. On the other hand, the lowest averages were detected from irrigation at $0.7 \mathrm{CPE}$ without addition of chitosan (control) in both seasons of study.

\section{Yield and Yield Components}

Results recorded in Table, 4 show that irrigation eggplants at 1.1 CPE gave the highest averages of fruit yield and yield components in both seasons. However, the lowest fruit yield (29.85 and 29.01 ton fad. ${ }^{1}$ in the $1^{s t}$ and $2^{n d}$, seasons, respectively) and yield components were detected from irrigation eggplants at 0.7 CPE (long intervals). It is obviously that increasing irrigation scheduling rate from 0.9 to 1.1 CPE significantly increased fruit No., fruit length, fruit diameter, fruit weight and fruit yield in 2017 season by 5.7, 48.1, 11.9, 4 and $4.35 \%$, respectively, and by $7.6,49.7,12.5,3.7$ and $4.4 \%$, in 2018 season, respectively

Concerning the effect of applying chitosan concentrates, results in Table 4 indicate that, fruit yield and its components were significantly affected except fruit length which exhibited no significant differences between $\mathrm{C}_{1}$ and $\mathrm{C}_{2}$ in both seasons. Foliar spray with chitosan at the concentrate of $80 \mathrm{mg}^{-1}$ gave the highest averages of yield and yield components, whereas, the lowest averages were detected from without addition of chitosan (control). Increasing the rate of chitosan from 40 to $80\left(\mathrm{mg} \mathrm{l}^{-1}\right)$, significantly increased fruit No./plant, fruit length $(\mathrm{cm})$, fruit diameter $(\mathrm{cm})$, fruit weight $(\mathrm{g})$ and fruit yield (ton fad. ${ }^{1}$ ) by $11.5,16.8,11.9,1.15$ and $2.83 \%$ in 2017 season, respectively, and in 2018 season by $14,18.5,9.8,1.25$ and $1.78 \%$, respectively.

Results in Table 4 reveal that, averages of yield and its components were significantly affected by the interaction between irrigation scheduling treatments and applying chitosan concentrates in both seasons. the highest averages of yield and yield components were observed from irrigation at $1.1 \mathrm{CPE}$ and applying $80 \mathrm{mg} \mathrm{l}^{-1}$ as chitosan concentrate, whereas the lowest ones were obtained from irrigation eggplant at $0.7 \mathrm{CPE}$ and without any addition of chitosan (control), these results were found to be true in both seasons (Mondal et al., 2012).

\section{Crop Water Relations}

\section{Seasonal consumptive use $\left(\right.$ ET $\left._{C}\right)$}

The results in Table 5 show that the values of seasonal consumptive use $\left(\mathrm{ET}_{\mathrm{C}}\right)$ as a function of irrigation scheduling regime and foliar spray with chitosan concentrates were 75.23 and $73.98 \mathrm{~cm}$ 
Table 3. Effect of irrigation scheduling, foliar spray with chitosan concentrates and their interactions on some eggplant growth parameter in 2017 and 2018 seasons

\begin{tabular}{|c|c|c|c|c|c|c|c|}
\hline \multirow{2}{*}{$\begin{array}{l}\text { Scheduling } \\
\text { Irrig. Treat. }\end{array}$} & \multirow{2}{*}{$\begin{array}{c}\text { Chitosan } \\
\text { Conc. rates } \\
\end{array}$} & \multicolumn{2}{|c|}{ Plant height (cm) } & \multicolumn{2}{|c|}{ Stem diameter $(\mathrm{cm})$} & \multicolumn{2}{|c|}{ Leaf No./plant } \\
\hline & & 2017 & 2018 & 2017 & 2018 & 2017 & 2018 \\
\hline$I_{1}$ & $\mathrm{C}_{1}$ & 68.6 & 66.5 & 2.3 & 2.2 & 95.4 & 94.6 \\
\hline \multirow[t]{2}{*}{1.1 (CPE) } & $\mathrm{C}_{2}$ & 69.3 & 67.1 & 2.4 & 2.3 & 114.8 & 112.7 \\
\hline & $\mathrm{C}_{3}$ & 71.4 & 69.3 & 2.8 & 2.6 & 125.6 & 123.8 \\
\hline \multicolumn{2}{|c|}{ Mean of $I_{1}$} & 69.8 & 67.6 & 2.5 & 2.4 & 111.9 & 110.4 \\
\hline$I_{2}$ & $\mathrm{C}_{1}$ & 66.4 & 65.6 & 2.1 & 2.0 & 93.1 & 92.8 \\
\hline \multirow[t]{2}{*}{0.9 (CPE) } & $\mathrm{C}_{2}$ & 66.7 & 66.1 & 2.3 & 2.2 & 98.9 & 97.6 \\
\hline & $\mathrm{C}_{3}$ & 68.3 & 66.9 & 2.6 & 2.5 & 105.3 & 104.1 \\
\hline \multicolumn{2}{|c|}{ Mean of $I_{2}$} & 67.1 & 66.2 & 2.3 & 2.2 & 99.1 & 98.2 \\
\hline$I_{3}$ & $\mathrm{C}_{1}$ & 63.5 & 62.4 & 1.9 & 1.7 & 88.2 & 87.5 \\
\hline \multirow[t]{2}{*}{0.7 (CPE) } & $\mathrm{C}_{2}$ & 64.0 & 63.3 & 2.1 & 1.9 & 93.6 & 92.3 \\
\hline & $\mathbf{C}_{3}$ & 65.5 & 64.2 & 2.4 & 2.3 & 96.1 & 95.0 \\
\hline \multicolumn{2}{|c|}{ Mean of $I_{3}$} & 64.3 & 63.3 & 2.1 & 2.0 & 92.6 & 91.6 \\
\hline Mean of & $\mathrm{C}_{1}$ & 66.2 & 64.8 & 2.1 & 2.0 & 92.23 & 91.6 \\
\hline \multirow[t]{2}{*}{ Chitosan } & $\mathrm{C}_{2}$ & 66.7 & 65.5 & 2.3 & 2.1 & 102.43 & 100.9 \\
\hline & $\mathbf{C}_{3}$ & 68.4 & 66.8 & 2.6 & 2.5 & 109.0 & 107.6 \\
\hline \multicolumn{8}{|c|}{ LSD at 0.05} \\
\hline \multicolumn{2}{|c|}{ I } & 1.3 & 1.2 & 0.1 & 0.1 & 5.2 & 4.9 \\
\hline \multicolumn{2}{|c|}{$\mathbf{C}$} & 0.4 & 0.4 & 0.1 & N.S & 4.4 & 4.6 \\
\hline \multicolumn{2}{|c|}{$\mathbf{I} \times \mathbf{C}$} & 0.9 & 0.8 & 0.1 & N.S & 4.6 & 4.3 \\
\hline
\end{tabular}

$\mathrm{C}_{1}$ : control, $\mathrm{C}_{2}: 40 \mathrm{mg}$ chitosan/l, $\mathrm{C}_{3}: 80 \mathrm{mg}$ chitosan/l, CPU: cumulative pan evaporation.

Table 4. Effect of irrigation scheduling, applying chitosan concentrates and their interactions on yield and yield components of eggplant in 2017 and 2018 seasons

\begin{tabular}{|c|c|c|c|c|c|c|c|c|c|c|c|}
\hline \multirow[t]{2}{*}{$\begin{array}{l}\text { Scheduling } \\
\text { Irrig. Treat. }\end{array}$} & \multirow[t]{2}{*}{$\begin{array}{c}\text { Chitosan } \\
\text { Conc. rates }\end{array}$} & \multicolumn{2}{|c|}{$\begin{array}{c}\text { Fruit } \\
\text { No./plant }\end{array}$} & \multicolumn{2}{|c|}{$\begin{array}{c}\text { Fruit length } \\
(\mathrm{cm})\end{array}$} & \multicolumn{2}{|c|}{$\begin{array}{l}\text { Fruit diameter } \\
(\mathrm{cm})\end{array}$} & \multicolumn{2}{|c|}{$\begin{array}{c}\text { Fruit weight } \\
\text { (g) }\end{array}$} & \multicolumn{2}{|c|}{$\begin{array}{c}\text { Fruit yield } \\
\text { ton/fad }^{-1}\end{array}$} \\
\hline & & 2017 & 2018 & 2017 & 2018 & 2017 & 2018 & 2017 & 2018 & 2017 & 2018 \\
\hline $\mathbf{I}_{1}$ & $C_{1}$ & 14.8 & 13.9 & 23.7 & 23.1 & 3.9 & 3.7 & 232.0 & 230.5 & 31.57 & 30.86 \\
\hline \multirow[t]{2}{*}{1.1 (CPE) } & $\mathrm{C}_{2}$ & 16.7 & 15.4 & 27.1 & 26.4 & 4.7 & 4.6 & 236.1 & 233.4 & 32.53 & 31.90 \\
\hline & $\mathrm{C}_{3}$ & 18.4 & 17.6 & 32.3 & 31.8 & 5.4 & 5.2 & 240.5 & 236.3 & 33.87 & 33.23 \\
\hline \multicolumn{2}{|c|}{ Mean of $I_{1}$} & 16.6 & 15.6 & 27.7 & 27.1 & 4.7 & 4.5 & 236.2 & 233.4 & 32.66 & 32.00 \\
\hline $\mathbf{I}_{2}$ & $\mathrm{C}_{1}$ & 14.1 & 13.2 & 15.4 & 14.7 & 3.6 & 3.4 & 224.7 & 222.4 & 30.14 & 29.44 \\
\hline 0.9 & $\mathrm{C}_{2}$ & 15.3 & 14.1 & 18.6 & 17.9 & 4.3 & 4.1 & 226.5 & 225.0 & 31.08 & 30.47 \\
\hline (CPE) & $\mathrm{C}_{3}$ & 17.6 & 16.3 & 22.2 & 21.6 & 4.8 & 4.5 & 230.0 & 227.5 & 32.67 & 32.03 \\
\hline \multicolumn{2}{|c|}{ Mean of $\mathrm{I}_{2}$} & 15.7 & 14.5 & 18.7 & 18.1 & 4.2 & 4.0 & 227.1 & 225.0 & 31.30 & 30.65 \\
\hline $\mathbf{I}_{3}$ & $\mathrm{C}_{1}$ & 13.4 & 12.5 & 13.5 & 12.9 & 3.2 & 3.0 & 214.4 & 211.0 & 28.35 & 27.71 \\
\hline 0.7 & $\mathrm{C}_{2}$ & 14.7 & 13.4 & 14.8 & 14.1 & 3.7 & 3.5 & 219.2 & 215.6 & 29.78 & 29.12 \\
\hline (CPE) & $\mathrm{C}_{3}$ & 16.3 & 15.0 & 16.4 & 16.0 & 4.0 & 3.8 & 213.1 & 218.7 & 30.85 & 30.21 \\
\hline \multicolumn{2}{|c|}{ Mean of $\mathbf{I}_{3}$} & 14.8 & 13.6 & 14.9 & 14.3 & 3.6 & 3.4 & 215.6 & 215.1 & 29.85 & 29.01 \\
\hline Mean of & $\mathrm{C}_{1}$ & 14.1 & 13.2 & 17.5 & 16.9 & 3.6 & 3.4 & 223.7 & 221.3 & 30.02 & 29.34 \\
\hline \multirow[t]{2}{*}{ Chitosan } & $\mathrm{C}_{2}$ & 15.6 & 14.3 & 20.2 & 19.5 & 4.2 & 4.1 & 225.3 & 224.7 & 31.45 & 30.50 \\
\hline & $\mathbf{C}_{3}$ & 17.4 & 16.3 & 23.6 & 23.1 & 4.7 & 4.5 & 227.9 & 227.5 & 32.34 & 31.04 \\
\hline \multicolumn{12}{|c|}{ LSD at 0.05} \\
\hline & & 0.6 & 0.7 & 3.6 & 4.1 & 0.3 & 0.4 & 7.5 & 6.6 & 1.1 & 0.8 \\
\hline & & 1.1 & 1.0 & 3.0 & 2.7 & 0.2 & 0.3 & 1.3 & 1. & 1.0 & 0.5 \\
\hline & & 0.5 & 0.4 & 2.8 & 3.3 & 0.2 & 0.2 & 2.5 & 2.4 & 0.9 & 0.6 \\
\hline
\end{tabular}

$\mathrm{C}_{1}$ : control, $\mathrm{C}_{2}: 40 \mathrm{mg}$ chitosan/l, $\mathrm{C}_{3}: 80 \mathrm{mg}$ chitosan/l, CPU: cumulative pan evaporation. 
Table 5. Effect of irrigation scheduling, applying chitosan concentrates and their interactions on seasonal consumptive use $\left(E T_{C}\right)$ of eggplant in 2017 and 2018 seasons

\begin{tabular}{|c|c|c|c|c|c|c|c|c|}
\hline \multirow{3}{*}{$\begin{array}{l}\text { Irrigation } \\
\text { (CPE) }\end{array}$} & \multicolumn{4}{|c|}{2017} & \multicolumn{4}{|c|}{2018} \\
\hline & \multicolumn{3}{|c|}{ Chitosan application rate } & \multirow[t]{2}{*}{ Mean } & \multicolumn{3}{|c|}{ Chitosan application rate } & \multirow[t]{2}{*}{ Mean } \\
\hline & $\mathrm{C}_{1}$ & $\mathrm{C}_{2}$ & $\mathbf{C}_{3}$ & & $\mathrm{C}_{1}$ & $\mathbf{C}_{2}$ & $\mathbf{C}_{3}$ & \\
\hline $\mathrm{I}_{1}: 1.1$ & 76.32 & 78.16 & 79.93 & 78.14 & 74.79 & 76.99 & 78.61 & 76.80 \\
\hline $\mathbf{I}_{2}: 0.9$ & 73.27 & 75.10 & 77.41 & 75.26 & 72.05 & 73.97 & 76.25 & 74.09 \\
\hline$I_{3}: 0.7$ & 69.82 & 72.61 & 74.45 & 72.29 & 68.53 & 71.32 & 73.27 & 71.04 \\
\hline Mean & 73.14 & 75.29 & 77.26 & 75.23 & 71.79 & 74.09 & 76.04 & 73.98 \\
\hline
\end{tabular}

$\mathrm{C}_{1}:$ control, $\mathrm{C}_{2}: 40 \mathrm{mg}$ chitosan/l, $\mathrm{C}_{3}: 80 \mathrm{mg}$ chitosan/l, CPU: cumulative pan evaporation.

in 2017 and 2018 seasons, respectively. Irrigation at 1.1 CPE exhibited the highest value of eggplant $\mathrm{ET}_{\mathrm{C}}$ comprised 78.14 and $76.80 \mathrm{~cm}$ in the two successive seasons, respectively. Irrigation at 0.9 or $0.7 \mathrm{CPE}$ seemed to decrease $\mathrm{ET}_{\mathrm{C}}$ by 3.7 and $7.5 \%$ in 2017 season and 3.5 and $7.5 \%$, in 2018 season, respectively, compared with irrigation at 1.1 CPE. The results could be attributed to decreasing the available soil moisture in the root zone of eggplant plants under $0.9 \mathrm{and} /$ or $0.7 \mathrm{CPE}$. These results are in accordance with those reported by Inalpulat $\boldsymbol{e t}$ al. (2014).

Regarding the effect of applying chitosan concentrates, results in Table 5 show that, applying $80 \mathrm{mg} \mathrm{l}^{-1}$ as chitosan concentrate produced the highest values of $\mathrm{ET}_{\mathrm{C}}$ reached 77.26 and $76.04 \mathrm{~cm}$ in 2017 and 2018 seasons, respectively. The lowest $\mathrm{ET}_{\mathrm{C}}$ values e.g. 73.14 and $71.79 \mathrm{~cm}$ in the two successive seasons, respectively, were detected from without addition (control). Moreover, applying $40 \mathrm{mg} \mathrm{l}^{-1}$ rate decrease $\mathrm{ET}_{\mathrm{C}}$ by 2.55 and $2.56 \%$ in 2017 and 2018 seasons, respectively comparing with 80 $\mathrm{mg} 1^{-1}$. These results may be due to the important role of chitosan to reduce transpiration of plants through its effect in closure of stomata which makes chitosan works as transpiration reducer to sustain water in agriculture (Bitteli et al., 2001).

Results in Table 5 show that, the highest averages of $\mathrm{ET}_{\mathrm{C}}$ values i.e. 79.93 and $78.61 \mathrm{~cm}$, in the two successive seasons, respectively, were obtained from irrigation scheduling at 1.1 CPE with applying chitosan at the rate of $80 \mathrm{mg} \mathrm{l}^{-1}$. On contrast, the lowest ones were detected from irrigation scheduling at $0.7 \mathrm{CPE}$ without any addition of chitosan i.e. 69.82 and $68.53 \mathrm{~cm}$ in 2017 and 2018 seasons, respectively.

\section{Water use efficiency (WUE)}

Results in Table 6 show that, water use efficiency average values, as affected by the irrigation scheduling treatments and rates of applying chitosan were 4.15 and $4.13 \mathrm{~kg}$ fruits yield $\mathrm{m}^{-3}$ water consumed in 2017 and 2018 seasons, respectively. The highest water use efficiency values of 4.18 and $4.17 \mathrm{~kg}$ fruits yield $\mathrm{m}^{-3}$ water consumed in the first and second seasons, respectively, were obtained from irrigation at 1.1 CPE, whereas, the lowest ones, i.e. 4.10 and $4.08 \mathrm{~kg}$ fruits yield $\mathrm{m}^{-3}$ water consumed in the two successive seasons were obtained from irrigation at $0.7 \mathrm{CPE}$

Concerning the applying chitosan concentrates, results in Table, 6 reveal that, the highest WUE averages i.e. 4.20 and $4.18 \mathrm{~kg}$ fruits yield $\mathrm{m}^{-3}$ water consumed in 2017 and 2018 seasons, respectively, were detected from applying $80 \mathrm{mg} \mathrm{l}^{-1}$ as chitosan concentrate. On the contrary, the lowest values were recorded in the control (without any addition) which comprised 4.10 and $4.09 \mathrm{~kg}$ fruits yield $\mathrm{m}^{-3}$ water consumed in the two successive seasons, respectively.

Results in Table 6 show that the highest WUE values, i.e. 4.24 and $4.23 \mathrm{~kg}$ fruits yield $\mathrm{m}^{-3}$ water consumed was obtained from irrigation at 1.1 CPE with applying $80 \mathrm{mg} \mathrm{l}^{-1}$ as chitosan concentrate in 2017 and 2018 season, whereas, the lowest ones i.e. 4.06 and $4.04 \mathrm{~kg}$ fruits yield $\mathrm{m}^{-3}$ water consumed obtained under irrigation eggplant plants at $0.7 \mathrm{CPE}$ without any addition of chitosan (control) in 2017 and 2018 seasons, respectively. 
Table 6. Effect of irrigation scheduling, applying chitosan concentrates and their interactions on water use efficiency (WUE) of eggplant in 2017 and 2018 seasons

\begin{tabular}{|c|c|c|c|c|c|c|c|c|}
\hline \multirow{3}{*}{$\begin{array}{l}\text { Irrigation } \\
\text { (CPE) }\end{array}$} & \multicolumn{4}{|c|}{2017} & \multicolumn{4}{|c|}{2018} \\
\hline & \multicolumn{3}{|c|}{ Chitosan application rate } & \multirow[t]{2}{*}{ Mean } & \multicolumn{3}{|c|}{ Chitosan application rate } & \multirow[t]{2}{*}{ Mean } \\
\hline & $\mathrm{C}_{1}$ & $\mathrm{C}_{2}$ & $\mathrm{C}_{3}$ & & $\mathrm{C}_{1}$ & $\mathrm{C}_{2}$ & $\mathbf{C}_{3}$ & \\
\hline $\mathrm{I}_{1}: 1.1$ & 4.14 & 4.16 & 4.24 & 4.18 & 4.13 & 4.14 & 4.23 & 4.17 \\
\hline $\mathbf{I}_{2}: 0.9$ & 4.11 & 4.14 & 4.22 & 4.16 & 4.09 & 4.12 & 4.20 & 4.14 \\
\hline $\mathbf{I}_{3}: 0.7$ & 4.06 & 4.10 & 4.14 & 4.10 & 4.04 & 4.08 & 4.12 & 4.08 \\
\hline Mean & 4.10 & 4.13 & 4.20 & 4.15 & 4.09 & 4.11 & 4.18 & 4.13 \\
\hline
\end{tabular}

$\mathrm{C}_{1}$ : control, $\mathrm{C}_{2}: 40 \mathrm{mg}$ chitosan/l, $\mathrm{C}_{3}: 80 \mathrm{mg}$ chitosan/l, CPU: cumulative pan evaporation.

\section{Conclusion}

In this investigation, the combined effect of three irrigation scheduling treatments and applying three chitosan concentrates on growth parameters, yield and its components and some water relations of eggplant (cv. Black Beauty $\mathrm{F}_{1}$ hybrid) were studied, and the results in the 2017 and 2018 seasons, show that:

-Irrigation at $1.1 \mathrm{CPE}$ with applying $80 \mathrm{mg} \mathrm{l}^{-1}$ gave the highest averages of plant height, stem diameter, leaf No./plant, fruit No./plant, fruit length, fruit diameter, fruit weight and fruit yield.

- Irrigation eggplant at 1.1 CPE increased fruits yield by 4.35 and $4.4 \%$, in the two successive seasons, respectively compared to those obtained by irrigation at $0.7 \mathrm{CPE}$.

-Applying $80 \mathrm{mg}^{-1}$ as chitosan concentrate increased the fruits yield by 2.83 and $1.78 \%$, in 2017 and 2018 seasons, respectively.

- The maximum values of seasonal consumptive use $\left(\mathrm{ET}_{\mathrm{C}}\right)$ having 79.93 and $78.61 \mathrm{~cm}$ in 2017 and 2018 seasons, respectively, when eggplant was irrigated at 1.1 CPE and applying chitosan concentrate of $80 \mathrm{mg} \mathrm{l}^{-1}$.

- The highest averages of WUE which amounted

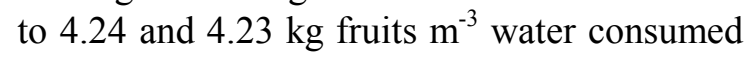
in the two successive seasons, respectively, were obtained from irrigated at 1.1 CPE with applying $80 \mathrm{mg} \mathrm{L}^{-1}$ as chitosan concentrate .
- Based on this investigation, it is worthy to advise the farmers under the trial conditions to irrigate eggplants at $0.9 \mathrm{CPE}$ (irrigation about every 18-21 days) with applying chitosan at the concentrate of $80 \mathrm{mg} \mathrm{l}^{-1}$ to achieve higher fruits yield with high WUE of eggplant crop to save water under water deficit conditions as the yield decreased by 4.5 to $4.6 \%$ (about 1.43 ton fad. ${ }^{1}$ ). Whereas, the irrigation water can be saved by 3 to $3.2 \%$ (236 to $252 \mathrm{~m}^{3}$ fad. $\left.{ }^{1}\right)$.

\section{REFERENCES}

Abdalla, M.M.A., H.Z. El-Dekashey, Dalia M.T. Nassef and G.Z.H. Kahlil (2018). Effect of irrigation intervals and genotypes on growth and yield of eggplant (Solanum melongena L.) I- Vegetative Growth. Assiut J. Agric. Sci., 49 (2) : 157-176.

Abdou, S.M.S., H.M. Abd El- Wareth and A.I. Aly (2018). Influence of sowing dates and irrigation scheduling on some water relations, snap bean (Phaseolus vulgaris L.) productivity and aphid (Acyrthosiphon pisum harris) populations Eypt. J. Appl. Sci., 33(9)

Amiri, E., A.A. Gohari and Y. Esmailian (2012). Effect of irrigation and nitrogen on yield, yield components and water use efficiency of eggplant. Afr. J. Biotechnol., 11 (13): 3070-3079.

Becker, T., M. Schlaak and H. Strasdeit (2000). Adsorption of nickel, zinc and cadmium cations by new chitosan derivatives. React. Funct. Polym., 44 (3): 289-298. 
Ben-Shalom, N., R. Ardi, R. Pinto, C. Aki and E. Fallik (2003). Controlling gray mould caused by Botrytis cinerea in cucumber plants by means of chitosan. Crop Protec., 22: $258-290$.

Bittelli, M.M., G. Flury, S. Campbell and E.J. Nichols (2001). Reduction of transpiration through foliar application of chitosan. Agric. and Forest Meteorol., 107: 167-175.

Chaves, M.M., J.P. Maroco and J.S. Pereira (2003). Understanding plant responses to drought from genes to whole plant. Fun. Plant Biol., 30:239-264.

Chen, W.G., X. Liu and H.X. Chen (2009). Preparation of modified chitosan with quaternary ammonium salt. Textile Bioeng. and Inform. Symposium Proc., 1: 226-230.

D'1az-Perez, J.C. and E.E. Touria (2015). Eggplant (Solanum- melongena L.) plant growth and fruit yield as affected by drip irrigation rate Hort., 50 (11):1709-1714.

Docimo, T., G. Francese, A. Ruggiero and G.De. Batelli (2016). Eggplant fruits: characterization of biosynthetic genes and regulation by a MYB transc ription factor. Front. Plant Sci., 6 : 1233. doi:10.3389/ fpls.2015. 01233.

George, M. and T.E. Abraham (2006). Polyionic hydrocolloids for the intestinal delivery of protein drugs: alginate and chitosan. J. Control Release, 114: 1-14.

Gomez, K.A. and A.A. Gomez (1984). Statistical Procedures for Agricultural Research, $2^{\text {nd }}$ Ed., Wiley and Sons, New York.

Gornik, K., M. Grzesik and B.R. Duda (2008). The effect of chitosan on rooting of grape vine cuttings and on subsequent plant growth under drought and temperature stress. J. Fruit Ornamental Plant Res., 16: 333-343.

Ibraheim, S.Kh.A. and A.A.M. Mohsen (2015). Effect of chitosan and nitrogen rates on growth and productivity of summer squash plants. Middle East J. Agric. Res., 4 (4): 673681.

Inalpulat, M., L. Genc, U. Kizil and S. Aksu (2014). Responses of eggplant to pruning under irrigation deficiency. Int. Conf. Biol.,
Civil and Environ. Eng. (BCEE-2014), Dubai (UAE).

Israelsen, O.W. and V.E. Hansen (1962). Irrigation Principles and Practices. $3^{\text {rd }}$ Ed., John Willy and Sons. Inc., New York.

Karimi, S., H. Abbaspour, J.M. Sinaki and H. Makarian (2012). Effects of water deficit and chitosan spraying on osmotic adjustment and soluble protein of cultivars castor bean (Ricinus communis L.). J. Stress Physio. Bio., 8: 160-169.

Kirnak, H., I. Tas, C. Kaya and D. Higgs (2002). Effects of deficit irrigation on growth, yield, and fruit quality of eggplant under semi- arid conditions. Aust. J. Agr. Res., 53 : 13671373.

Klute, A. (1986). Methods of Soil Analysis. Part-1: Physical and Mineralogical Methods $\left(2^{\text {nd }}\right.$ Ed.) Ame. Soc. Agron., Madison, Wisconsin, USA.

Mondal, M.M.A., M.A. Malek, A.B. Puteh, M.R. Ismail, M. Ashrafuzzaman and L. Naher (2012). Effect of foliar application of chitosan on growth and yield in okra. AJCS, 6: 918-921.

Page, A.L., R.H. Miller and D.R. Keeney (1982). Methods of Soil Analysis. Part-2: Chemical and Microbiological Properties. $\left(2^{\text {nd }}\right.$ Ed.) Ame. Soc. Agron., Madison, Wisconsin. USA.

Photchanachai, S., J. Singkaew and J. Thamthong (2006). Effect of chitosan seed treatment on Colletotrichum sp. and seedling growth of chili cv. "Jinda". Acta Hort., 712: 585-590.

Plazas, M., M.P. López-Gresa, S. Vilanova, C. Torres, M. Hurtado and P. Gramazio (2013). Diversity and relationships in key traits for functional and apparent quality in a collection of eggplant: fruit phenolics content, antioxidant activity, polyphenol oxidase activity, and browning. J. Agric. Food Chem., 61: 88718879 .

Sheikha, S.A.A. and F.M. Al-Malki (2011). Growth and chlorophyll responses of bean plants to the chitosan applications. Europ. J. Sci. Res., 50 (1):124-134. 
Sugiyama, H., K. Hisamichi, K. Sakai, T. Usui, J.I. Ishiyama, H. Kudo, H. Ito and Y. Senda, (2001).The conformational study of chitin and chitosan oligomers in solution. Bioorganic and Med. Chem., 9: 211-216.
Vites, F.G. (1965). Increasing water use efficiency by soil management in plant environment and efficient water use. J. Ame. Soc. Agron., 26: 537-546.

$$
\begin{aligned}
& \text { حث إنتاجية الباذنجان من خلال معاملات جدولة الري والرش بتركيزات من الثيتوزان }
\end{aligned}
$$

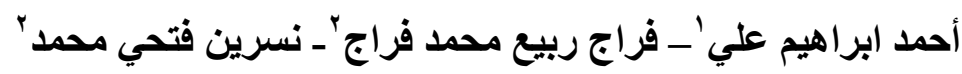

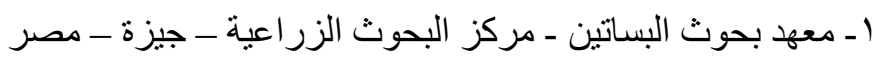

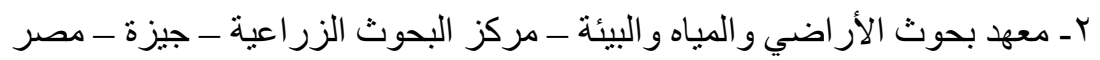

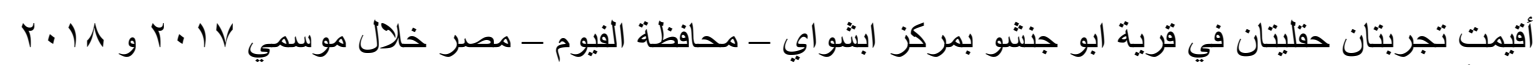

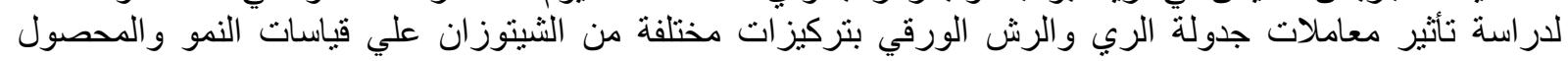

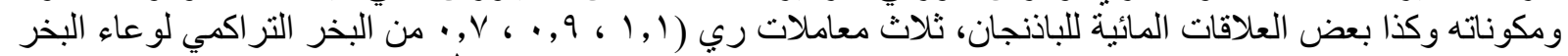

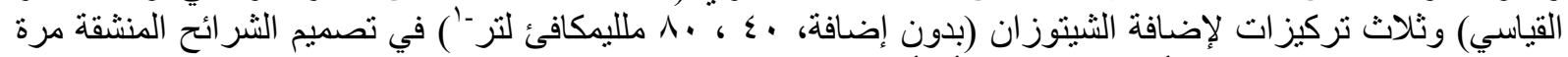

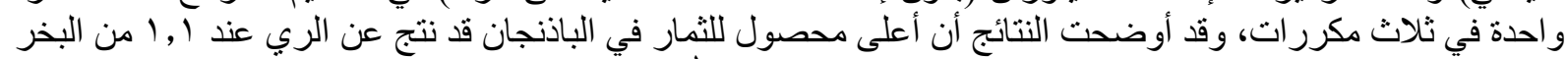

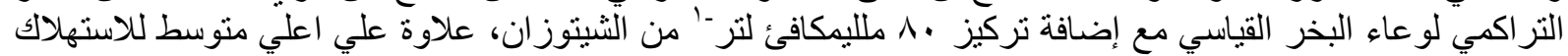

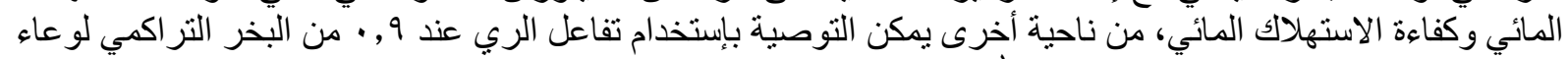

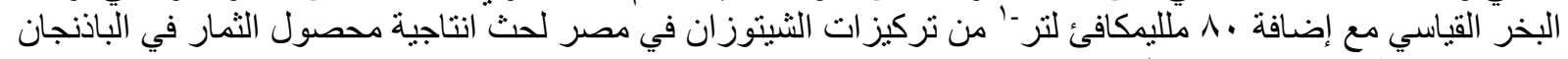
خاصة تحت ظروف نقص مياه الري. 